\title{
A Survey on the Use of Causal Discourse Markers among Chinese English Majors
}

\author{
Yafei Zhang ${ }^{1} \&$ Huaqing $\mathrm{He}^{1}$ \\ ${ }^{1}$ School of Foreign Languages, China West Normal University, Nanchong, China \\ Correspondence: Huaqing He, School of Foreign Languages, China West Normal University, No. 1 Shi Da Road, \\ Nanchong, 637009, Sichuan, China. Tel: 86-817-231-1856. E-mail: masha4567@sina.com
}

Received: July 4, 2015 Accepted: July 26, 2015 Online Published: September 29, 2015

doi:10.5539/ijel.v5n5p126 URL: http://dx.doi.org/10.5539/ijel.v5n5p126

This research is financed by the Department of Education of Sichuan Province, China (Project No. 13SA0015).

\begin{abstract}
Chinese English Majors mainly write argumentative compositions which itself is a kind of causal relations. Thereby, causal discourse markers, as one of the Discourse Markers can be employed in their argumentations to tighten the coherence and logical relations. Based on the results of other scholars' previous research, this thesis applies questionnaires to investigate the reasons of using causal discourse markers in English majors' oral and written English. According to the analysis of questionnaires, the reasons that caused English majors using of causal discourse markers are as follows: 1) lack of stylistic awareness; 2) intentionally avoiding making mistakes; 3) time factor (timed); 4) negative L1 transfer; 5) teachers' influence. The results generated from the data analysis and discussions have also provided some pedagogical implications.
\end{abstract}

Keywords: causal discourse markers, English majors, oral and written English, questionnaire

\section{Introduction}

Connectives have become a new researching field in conversation analysis and grammatical study over the years since Quirk (1985) found out that the linguistic phenomenon that there were many recurrent adjuncts in oral English, such as well, you see, you know, because, etc.. In English writing and speaking, visible connective elements are necessary for the leaners to complete the meaning of context. Discourse markers are considered as these kinds of visible connective elements which are commonly employed to express various logical relations between sentences or paragraphs which can make people better comprehend the whole context. As one of the DMs (Discourse markers), causal discourse markers are commonly employed to express logical causal relations for linking sentences.

The essence of argument, then, is reason, and reason may work in two ways: be deduction and induction (Doug, 2005). Thus it can be seen that causal DMs play a fundamental role in spoken and written argumentative compositions. Given the fact that Chinese English majors mainly write argumentative compositions, and argumentative writing itself is a kind of causal relation, thereby, they can use causal DMs in their argumentations to tighten the coherence and logical causal relations Since many researchers at home and abroad have been taken advantage of corpora to investigate the EFL (English as Foreign Language) learners' using features of CDMs, this paper is going to employ a questionnaire to explore the deeper reasons caused their using features on the use of CDMs.

\section{Literature Review}

There are some investigations related to the use of CDMs by EFL (English as Foreign Language) learners at abroad. For instance, Hays (1992,) discovered that EFL learners employ so frequently. Schleppegrell (1996) did a survey on the use strategies of because by EFL learners and found that EFL cannot use because suitably, that is the learners ignored the pragmatic differences of DMs in spoken English and written English. Altenberg and Trapper (1998) revealed that Swedish students cannot employ therefore and thus properly like native speakers, particularly in argumentative compositions. That is to say there exists the problem of using CDMs between students. 
Similarly, our Chinese researchers also discover some problems on the use of CDMs by our own students. Mo Junhua(2005) pointed out that the density of CDMs Chinese students use is more and the diversity is less than the native speakers'. The CDMs they are inclined to use are concentrated on so, because and therefore etc. And their stylistic awareness is not very clear. Cai Yan (2005)'s results show that the frequency of placing adverbial because-clause before the principle clause by Chinese English learners is higher than that of native speakers due to students' negative L1 transfer. And the higher proficiency of English, the fewer phenomena of Chinese English learners put adverbial because-clause before the principle clause and the lower rate of using the structure of because... so.... Chen Xinren \& Wu Yu's (2006) results show that Chinese English Learners can commonly use the CDMs to describe the causal relations properly but they also overuse and avoid using some CDMs. Tang Liling's (2011) results indicate that English majors coexist the problem of overusing and underusing the CDMs in their written English. The CDMs they overuse such as so and as a result occur earlier in their textbooks and the CDMs they underuse such as therefore, hence, and thus are those often employed in native speakers' writings. Some specific CDMs used by them are characteristic by the pragmatic fossilization.

These investigators take advantage of corpus to explore the features of using CDMs by EFL, which make a great contribution to the field of studying CDMs, language teaching and learning, and the second language acquisition. But the reasons that affect their using of CDMs are still staying in speculating. It is therefore this essay tries to explore the deeper reasons on the using of this kind of discourse markers by Chinese English majors based on the questionnaire data.

Based on the results of other scholars' previous research, this thesis applies questionnaires to investigate the reasons that cause Chinese English majors' use of CDMs.

\section{Method}

\subsection{Participants}

The subjects for this investigation are 135 sophomores who major in English teaching from China West Normal University in Sichuan Province.

\subsection{Questionnaire}

The author designed a questionnaire (See Appendix A) covering 12 questions to inquiry the using condition of CDMs by English majors in their oral and written English. All the questions which are handed out to the subjects are written in Chinese for better comprehending (See Appendix B).

There are 2 items about the ground information of the subjects. After this personal information, it is the major part of the questionnaire which consists of twelve items. 1 item is designed to check whether the subjects are familiar with some CDMs which the present research studies. 2 items investigate the CDMs which are most often used in their writing and speaking. 4 items are designed to explore the potential factors that affect the students' using CDMs in writing and speaking. 1 item is made to check whether the subjects take note of the importance of using CDMs in English writing and speaking. 4 items are designed to examine the teaching condition of CDMs in class.

\subsection{Procedures}

In order to ensure there aren't any possible mistakes or misunderstandings on the diction, the investigator conducted a pilot study under the assistances of investigator's classmates.

With the help of their English teachers, the questionnaires were handed out at 7:00 pm on 2/26/2014 which were during the normal class time for guaranteeing the seriousness. Before distribution, the author gave a brief but clear introduction to the requirement for responding to the questionnaire, which helps to better guarantee the authenticity of the answer:

1) What they should do was to answer the questions in the light of their own experiences and situations, they don't need to be afraid if the answers were correct or not.

2) In view of some CDMs have other meanings apart from the causal meaning, the researcher had called student's attention to notice the aim of Q1 in questionnaire is to let them write out the meaning expressing causal relation without referring to dictionary.

3) According to situation of the pilot study, the investigator should remind the students this questionnaire has two sides.

All questionnaires were carefully checked by the author, 4 students' questionnaires were kicked out as a result of missing information. That is to say, only 131 valid questionnaires were taken back. 


\section{Results}

This questionnaire is designed to explore the reasons on the use of CDMs in English majors' spoken and written English. After a careful calculation and analysis for the questionnaires, the author gets the following results.

Table 1. CDMs that English majors are most familiar with (data of Q1)

\begin{tabular}{lll}
\hline Item & No & Per \\
\hline because & 131 & 100 \\
so & 127 & 96.95 \\
because of & 126 & 96.18 \\
due to & 124 & 94.65 \\
therefore & 122 & 93.13 \\
owing to & 118 & 90.08 \\
thanks to & 118 & 90.07 \\
for & 115 & 87.79 \\
now that & 113 & 86.30 \\
thus & 109 & 83.20 \\
hence & 107 & 81.68 \\
consequently & 104 & 79.39 \\
as a consequence & 95 & 72.52 \\
on account of & 94 & 71.75 \\
since & 80 & 61.07 \\
thereby & 74 & 56.49 \\
for this reason & 70 & 53.43 \\
in view of & 63 & 48.09 \\
in response to & 57 & 43.51 \\
as a result of & 47 & 35.88 \\
accordingly & 23 & 17.56 \\
in consequence & 13 & 9.92 \\
\hline
\end{tabular}

Note. No. $=$ number, Per. $=$ percentage.

Table 1 is the data of Q1. The aim of Q1 is to investigate whether English majors are familiar with these CDMs. Although the designation of Q1 may exist some potential queries, for example, some students may not want to write down the meanings of them seriously on account of thinking it is so easy, and some other students may write down the non-causal meaning of these CDMs which has other semantic meanings though they know the causal logical concept. For example, here are four students regards so as the adverb of degree. Yet, regardless of these negative sides, the designation of Q1 also has its positive aspects. It will help students make a review to these CDMs as well as have an intuitive understanding to know what the CDMs are, which can supply students a better foundation to answer the following questions. Those CDMs which they don't write out are classified into the wrong items. As we can see, $100 \%$ of these students know the correct meaning of because. That is to say, the English majors are very familiar with this kind of CDM. The other types of CDMs they are familiar with are so, because of, due to, therefore, owing to, thanks to. More than $50 \%$ of students are not familiar with in view of, in response to, as a result of, accordingly, in consequence.

Table 2. CDMs are most often used by English majors in spoken and written English (data of Q2 and Q3)

\begin{tabular}{|c|c|c|c|c|c|c|}
\hline \multicolumn{4}{|c|}{ Written English } & \multicolumn{3}{|c|}{ Spoken English } \\
\hline Item & & No & Per & Item & No & Per \\
\hline 1 & because & 128 & 97.71 & because & 131 & 100 \\
\hline 2 & because of & 98 & 74.81 & so & 114 & 87.02 \\
\hline 3 & so & 92 & 70.23 & because of & 84 & 64.12 \\
\hline 4 & therefore & 77 & 58.78 & for & 73 & 55.72 \\
\hline 5 & for & 76 & 58.01 & thanks to & 53 & 40.46 \\
\hline 6 & since & 53 & 40.46 & therefore & 48 & 36.64 \\
\hline 7 & thanks to & 52 & 39.70 & since & 47 & 35.88 \\
\hline 8 & due to & 49 & 37.40 & due to & 32 & 24.43 \\
\hline 9 & now that & 38 & 29.01 & thus & 24 & 18.32 \\
\hline 10 & owing to & 35 & 26.72 & now that & 22 & 16.79 \\
\hline 11 & thus & 32 & 24.43 & as a result of & 22 & 16.79 \\
\hline
\end{tabular}




\begin{tabular}{|c|c|c|c|c|c|c|}
\hline 12 & as a result of & 32 & 24.43 & for this reason & 17 & 12.98 \\
\hline 13 & consequently & 25 & 19.08 & as a consequence & 9 & 6.87 \\
\hline 14 & as a consequence & 23 & 17.56 & consequently & 8 & 6.11 \\
\hline 16 & for this reason & 16 & 12.21 & in view of & 7 & 5.34 \\
\hline 17 & hence & 15 & 11.45 & owing to & 6 & 4.58 \\
\hline 20 & thereby & 6 & 4.58 & thereby & 3 & 2.29 \\
\hline 21 & accordingly & 6 & 4.58 & accordingly & 3 & 2.29 \\
\hline 22 & in consequence & 3 & 2.29 & in consequence & 1 & 0.76 \\
\hline
\end{tabular}

Note. No. $=$ number, Per. $=$ percentage.

Q2 and Q3 seek to investigate which CDMs are most often used by English majors in their written and spoken English respectively. These discourse markers which the subjects don't write down correctly in Q1 will not be counted in Q2 and Q3. Table 2 shows that $100 \%$ of them choose because as their most often used CDMs in their spoken English. Similarly, the percentage of because in their written English is $98 \%$ which ranks at the first place. Besides, more than half of them all choose because, so, because of, for whether in their spoken English or written English. The reasons why they are so often used are investigated in Q4 (see Table 3). 68\% of them consider that they just use them unconsciously, and $27 \%$ of them think that they don't want to make any mistakes. That is to say, those students are very familiar with these CDMs and they know the meaning and usage of them. They have preference for choosing such simple markers to organize their expression. As for the data of questionnaires, most of the English majors choose because and so in their written English. It shows that they are lack of stylistic awareness.

Table 3. Data of the questionnaires $(\mathrm{Q} 4-\mathrm{Q} 12)$

\begin{tabular}{|c|c|c|c|c|c|c|c|c|}
\hline & $\mathbf{A}$ & & B & & C & & D & \\
\hline & No & Per & No & Per & No & Per & No & Per \\
\hline Q4 & 35 & 26.72 & 10 & 7.63 & 89 & 67.94 & 2 & 1.53 \\
\hline Q5 & 112 & 85.50 & 4 & 3.05 & 12 & 9.16 & 3 & 2.29 \\
\hline Q6 & 38 & 29.01 & 10 & 7.63 & 80 & 61.07 & 3 & 2.29 \\
\hline Q7 & 9 & 6.87 & 77 & 58.78 & 45 & 34.35 & 0 & 0 \\
\hline Q8 & 10 & 7.63 & 55 & 41.98 & 60 & 45.80 & 6 & 4.58 \\
\hline Q9 & 22 & 16.79 & 101 & 77.10 & 7 & 5.34 & 1 & 0.76 \\
\hline Q10 & 4 & 3.05 & 23 & 17.56 & 85 & 64.89 & 19 & 14.50 \\
\hline Q11 & 4 & 3.05 & 10 & 7.63 & 79 & 60.31 & 38 & 29.01 \\
\hline Q12 & 25 & 19.08 & 73 & 55.73 & 31 & 23.66 & 2 & 1.53 \\
\hline
\end{tabular}

Note. $\mathrm{Q}=$ question, No. $=$ number, Per. $=$ percentage.

Q5 and Q6 discuss whether the time will affect their choice of choosing CDMs. Q5 investigates the situation under the timed condition, it finds that $86 \%$ of the students will choose simple CDMs which they are very familiar with when they are in timed writing tests, the data shows that is because they don't have enough time for thinking up other types of CDMs. While under the condition of untimed writing assignments, $61 \%$ of them will consciously avoid using the easiest and the most common types of CDMs for the sake of seeking the diversity of words in their productions. Meanwhile, there are also some students $(29 \%)$ who would like to use the CDMs which they are familiar with in case of making mistakes.

Q7 intends to examine the consciousness of using CDMs in their spoken and writing productions. $59 \%$ of the students claim that they often use causal discourse markers in their compositions. It indicates that the majority of them have strong awareness of using causal discourse markers in their productions. While $7 \%$ of them always use these causal discourse markers in compositions. It means that they must overuse causal discourse markers in their productions. None of them say that they never use any causal discourse markers in their English productions.

The investigation of whether the English majors are under the influence of Chinese way of thought is discussed in Q8. Basically $45 \%$ of them respectively say that they often and sometimes keep Chinese causal discourse markers in mind in the process of English creation. It reveals that the great proportion of so and because in 
questionnaires (see Table 1 and Table 2) can be attributed to Chinese transfer. However, only a small proportion of them $(5 \%)$ never keep Chinese discourse markers in mind while they are writing or speaking.

Q9 discovers $77 \%$ of the students are aware of the importance of using causal discourse markers in their productions. And $17 \%$ of them think causal discourse markers are very important.

Q10 is designed to investigate if the English teachers pay much attention to the teaching of causal discourse markers in class time. $65 \%$ of the students claim that their English teachers just instruct knowledge about causal discourse markers sometimes, even $15 \%$ of the students hold that their teachers never introduce the meaning or usage of causal discourse markers in the process of teaching.

Q11 intends to find out whether English teachers attach great importance to the teaching of correct style of these CDMs when they are guiding English writing and speaking. $60 \%$ of them claim that their teachers sometimes emphasize the style of CDMs in writing and speaking guidance, and $8 \%$ of them say "often". Yet, up to $29 \%$ of these students hold that their teachers never emphasize the style of CDMs.

Q12 reveals that nearly all of them (98\%) insist that it is necessary to make an explanation and do some exercises for causal discourse markers in class time.

Generally speaking, the following phenomenon is the reflection of the results of this questionnaire. First, because, so, because of, due to, therefore are the most familiar CDMs to English majors. In view of knowing the meaning of usage of these CDMs very well, the students have the tendency to employ simple CDMs in their English speaking and writing. Yet, the large proportion of using because and so illustrates that English majors are lack of stylistic awareness. Second, English majors will choose different types of CDMs in accordance with timed and untimed situation. Third, most English teachers are aware of the importance of CDMs in their writing and speaking, and they have strong awareness of employing them in their productions. Fourth, nearly half of the students are influenced by their Chinese thoughts and their overuse of some simple CDMs can be attributed to the negative transfer of L1 (Chinese). It reflects that the acquisition of CDMs by English majors is influenced by L1 (Chinese). Fifth, more than half of English teachers occasionally teach the usage and functions of CDMs in class time and emphasize the stylistic features of CDMs in English written and spoken guidance. And nearly $30 \%$ of teachers never mention them during the teaching. This means it's urgent for teachers to improve student's stylistic awareness by guiding them to pay much attention to the stylistic features of each CDM.

\section{Discussion}

In the light of statistics of the questionnaires, this paper summarizes the following primary reasons that lead to the features of using CDMs by Chinese English majors:

\section{1) Lack of Stylistic Awareness}

Learners' lack of stylistic awareness means they tend to use lots of expressions which should be employed in the spoken English in their written productions. Alterberg has calculated the percentage of because and so appeared in the spoken and written English (Biber, 2000). The result shows that because and so account for $74 \%$ in the spoken corpus LLC (London-Lund Corpus of spoken English) and only 19\% in the written English corpus LOB (the Lancaster-Oslo/Bergen Corpus), which is similar to the statists calculated in Table2. Alterberg's study shows that because and so is usually appeared in the spoken English, that is to say they are not the formal style.

As it can be seen from Table 2 (the data of Q2), 97\% and 70\% of Chinese English majors choose because and so respectively as their frequently-used CDMs in their argumentative writings. It shows that Chinese English majors don't realize so and because are informal words which are often used in the oral English.

2) Intentionally Avoiding Mistakes

English study as one of the foreign language leaning for Chinese students. They usually incline to employ the familiar and frequently used expressions to organize their dissertation for the reason of learners' insufficient vocabularies and for the fear of making mistakes. The statistics of Q4 in Table 3 show that 27\% of English majors choose their most often used CDMs in Q2 and Q3 are because they will not make any mistakes. It illustrates English majors are consciously to use the familiar causal discourse markers for avoiding mistakes.

3) Time Factor

Wang and Zhu (2005) in their Chinese EFL learner's use of DMs in spoken language pointed out that the overuse of very and I think is probably due to the communication pressure and poor language anxiety. To be more specific, learners may feel pressured under the certain situational anxiety. Table 1 shows that students are very familiar with the CDMs of so, because, because of, for, therefore, thanks to, and they are also chose them as their most frequently-used CDMs in spoken English (Q3). Meanwhile, 85\% of English majors claim that they 
will choose simple CDMs which they are very familiar with due to the lack of time under the condition of examination. Oral examination occurs in real time, it requires instantaneous cognitive processing. As speakers are taking the oral examination, they will feel pressured and prefer to choose some simple words they are very familiar with in order to ensure the fluency of their communication.

4) Negative L1 Transfer

Negative transfer occurs when learners' projection of L1 pragmatic to L2 result in their speech behaviors' feature different from L2 native foreigners. Specifically, the Chinese learners may directly translate the Chinese into the English equivalents or their familiar expressions.

Compared to the native speakers, Chinese English learners tend to place adverbial because-clause before the principle clause and use the speech error structure "because...so..." which are equivalent to the Chinese language pattern“因为....... 所以..." Cai Yan (2005). She believes what makes this happens is due to the negative transfer of their native language. Similarly, the data of Q8 of the questionnaires (See Table 3) also reflects that most Chinese English majors are influenced by their Chinese thought on the using of CDMs when they are speaking and writing.

5) Teachers' Influence to Students on CDMs Use

Krashen (1982) has mentioned that input is the primary condition in second language acquisition. The key to successful language acquisition is what to input and how to input. In foreign language learning contexts, language input occurs almost entirely in classrooms where the teachers share the same L1 and cultural backgrounds as their students, and where only a limited range of social interactions is provided. So to speak, the use of CDMs appeared in teachers' talk is one of the fields that affects learner's linguist input of CDMs' knowledge in class time,

The questionnaire survey has found that $15 \%$ of the English teachers don't teach students the knowledge of CDMs and $29 \%$ of them don't guide their students to make a clear distinction between formal and informal style in the class. Apparently, there will be not any exercises about the usage of CDMs for helping students acquire CDMs in the teaching process.

\section{Conclusion}

According to the results of previous studies on the use of CDMs which have mentioned before, the goal of this paper is to explore the reasons that cause Chinese English majors' using of CDMs through the questionnaire. And the analysis finally shows that there are mainly five factors that influence their using of CDMs, which are lack of stylistic awareness, intentionally avoiding making mistakes, time factor, negative L1 transfer and teacher's influence. Since the present study has mentioned that CDMs play a very crucial role in Chinese English majors' oral and written argumentations at the beginning of this paper, it is necessary to provide some pedagogical implications for the language learning and teaching to improve their discourse competence in terms of employing the CDMs.

English teachers should guide students to notice the stylistic difference between oral and written English and introduce more kinds of CDMs to students in real context instead of simply translating them into Chinese. For example, teachers can set up an authentic and comfortable learning environment to help students access to the authentic and interesting materials such as English novels, movies, or soap operas and so on that involved the using of CDMs. Then teachers can lead students to have discussions in group or pair work. That is due to the reasons of speaking in small groups can make students feel less nervous and more confident to express their opinions than speaking in the front of many people. Let students use the given words or phrases to do these activates and teachers can offer some suggestions to guide students to use these given words properly and correctly

And students should attach their attentions to the styles of words or phrases in the process of remembering them. And at same time, they should not only enlarge their vocabularies through memorizing or any other methods relating to the language input, but also to do enough exercises to practice them such as speaking and writing which is the category of language output to consolidate the words and phrases they have remembered.As the saying goes, practices makes perfect. With enough practices has been done, more mistakes have showed out, more confident has built up and less anxiety has appeared all these will promote students to improve themselves effectively. 


\section{References}

Altenberg \& Tapper. (1998). The use of Aderbial Connectors in Advanced Learners written English. London \& New York: Longman: 80-93.

Biber, D. et al. (2000). Longman Grammar of Spoken and Written English. Beijing: Foreign Language Teaching and Research Press.

Cai, Y. (2005). A Tentative Study on Chinese Learners' Acquisition in the Causal Adverbial Clause Introduced by 'Because'. Journal of Guangxi Teachers Education University (Philosophy and Social Sciences Edition). Retrieved

from http://www.cnki.net/KCMS/detail/detail.aspx?QueryID=2\&CurRec=1\&dbcode=CJFQ\&dbname=CJFD200 $5 \&$ filename $=$ SYXI200504024\&urlid $=\& y x=\& v=M j I 2 N D g 3 R G g x V D N x V H J X T T F G c k N V U k w r Z 11 P Z H F G$ Q3JsVmJ6Qk5qVFRaN0c0SHRUTXE0OUhZSVI4ZVgxTHV4WVM=

Chen, X. R., \& Wu, Y. (2006). The Use of Causal Discourse Markers by Chinese English Learners-A Corpus-based Research. Foreign Language Teaching Abroad. Retrieved from http://www.cnki.net/KCMS/detail/detail.aspx?QueryID=0\&CurRec=13\&dbcode=CJFQ\&dbname=CJFD20 06\&filename $=$ GWJX200603007\&urlid $=\& y x=\& v=$ MjQ0NjRSTCtmWU9kcUZDcm1 VTHJOSWpyQmRyR zRIdGZNckk5Rlk0UjhlWDFMdXhZUzdEaDFUM3FUcldNMUZyQ1U=

Doug, V. (2005). Public Relations Writing: Form \& Style. Belmont: Wadsworth Publishing Co Inc.

Hays, P. R. (1992). Discourse markers and L2 acquisition. Applied Linguistics-Michigan, (7), 24-34.

Huang, D. W. (2001). A Survey of Discourse Markers. Foreign Languages in Fujian. Retrieved from http://www.cnki.net/KCMS/detail/detail.aspx?QueryID $=5 \&$ CurRec $=1 \&$ dbcode $=$ CJFQ \&dbname=CJFD200 1\&filename $=$ FJWY200101001\&urlid $=\& y x=\& v=$ MDU1MzdZUjhlWDFMdXhZUzdEaDFUM3FUcldNMU ZyQ1VSTCtmWU9kcUZDcm1VYnpNSXImY2Q3RzRIdERNcm85Rlo=

Krashen, S. (1982). Principles and Practice in Second Language Acquisition. Oxford: Pergamon.

Mo, J. H. (2005). A Corpus Study on the Use of Causal Discourse Markers in Chinese Learners' Argumentation. Foreign Language Education. Retrieved from http://www.cnki.net/KCMS/detail/detail.aspx?QueryID=10\&CurRec=2\&dbcode=CJFQ\&dbname=CJFD20 $05 \&$ filename $=$ TEAC200505010\&urlid $=\& \mathrm{yx}=\& \mathrm{v}=$ MDMwMzVUcldNMUZyQ1 VSTCtmWU9kcUZDcm 1 VYnZJTVNqS2JiRzRIdFRNcW85RVpJUjhlWDFMdXhZUzdEaDFUM3E=

Quirk, R. (1985). A Comprehensive Grammar of the English Language. London \& New York: Longman.

Tang, L. L. (2011). An Investigation of Cause-Result Discourse Markers in Chinese EFL Learners' Written English-A Corpus-based Research. Journal of Lanzhou Jiaotong University. Retrieved from http://www.cnki.net/KCMS/detail/detail.aspx?QueryID=15\&CurRec=16\&dbcode=CJFQ\&dbname=CJFD2 011\&filename $=$ LZTX201105034\&urlid $=\& y x=\& v=$ MjYyOTk4ZVgxTHV4WVM3RGgxVDNxVHJXTTF GckNVUkwrZllPZHFGQ3JtVnIzSUtUZmZkckc0SDlETXFvOUdZSVI=

Wang, L. F., \& Zhu, W. H. (2005). A Study on the Use of Discourse Markers in Chinese Learners' Spoken English. Foreign Languages Research. Retrieved from http://www.cnki.net/KCMS/detail/detail.aspx?QueryID=26\&CurRec $=4 \& d b c o d e=C J F Q \& d b n a m e=C J F D 20$ 05\&filename $=$ NWYJ200503009\&urlid $=\& y x=\& v=$ MjkzNThSOGVYMUx1eFlTN0RoMVQzcVRyV00xRn JDVVJMK2ZZT2RxRkNybVZML05LenJTWkxHNEh0VE1ySTlGYlk=

\section{Appendix A}

\section{Questionnaire (English version)}

Grade:

Major:

This questionnaire is designed to explore the use CDMs in English majors' written and spoken English. Please finish it according to your own reality. There is not true or false with answers and it will not influence your school record. It is just for the teaching research.

1. Please write out the meanings of these CDMs.

because

therefore for

thereby since

thus so

hence 


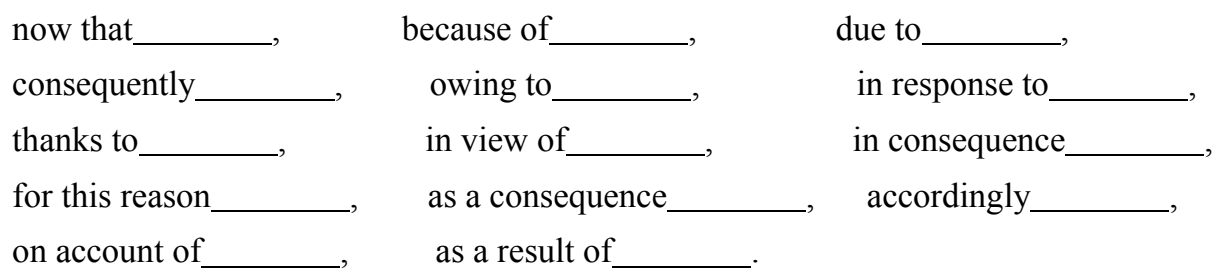

2. Please check the following CDMs which are most often used in your writing.

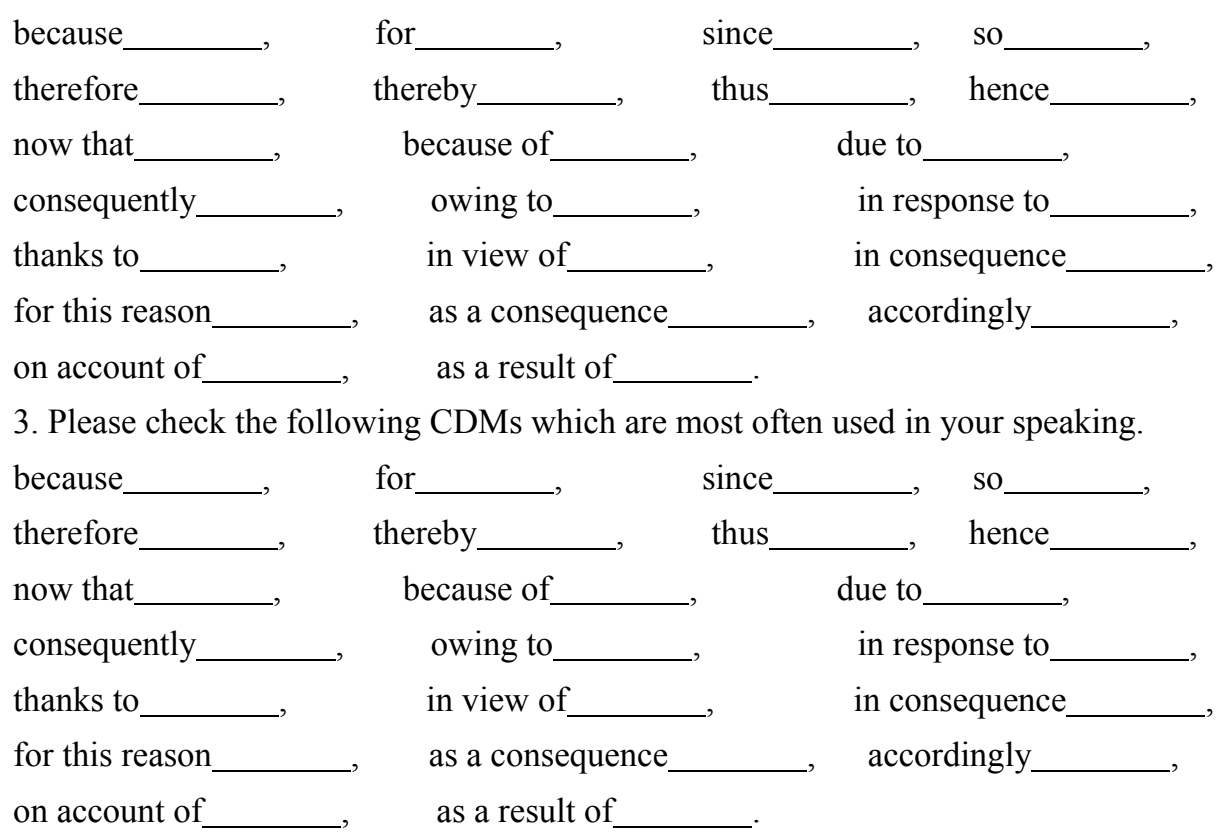

4. Why do you often use them?
A. It is not likely to make mistakes.
B. They are similar to those in Chinese
C. I use them unconsciously.
D. Other reasons.

5. Which of the following circumstances do you meet in timed examination?
A. I will choose the simple and familiar CDMs due to the limited time.
B. I will choose those CDMs which are similar in Chinese.
C. I will avoid to use the most common and simple CDMs consciously.
D. other situations.

6. Which of the following circumstances do you meet in untimed examination?
A. I will choose the simple and familiar CDMs.
B. I will choose those CDMs which are similar in Chinese.
C. I will avoid to use the most common and simple CDMs consciously.
D. other situations.

7. How often do you use CDMs in your writing and speaking?
A. Always
B. Often
C. Sometimes
D. Never

8. Will you think of Chinese CDMs in the process of writing and speaking?
A. Always
B. Often
C. Sometimes
D. Never

9. What do you think of the roles of CMDs in English writing and speaking?
A. Very important
B. Important
C. Not very important
D. Unimportant

10. Does your English teacher instruct the knowledge about CDMs in teaching?
A. Always
B. Often
C. Sometimes
D. Never 
11. Does your English teacher emphasize the style of CDMs in the teaching process?
A. Always
B. Often
C. Sometimes
D. Never

12. What do you think of explaning and doing some exercise for CDMs in class?
A. Much necessary
B. Necessary
C. Little necessary
D. Unnecessary

\section{Appendix B}

\section{Questionnaire (Chinese version)}

\section{调查问卷}

年级: 专业:

本问卷是为了了解英语专业学生在英语写作和口语中使用话语标记语的情况而设计。请根据你的实际情 况认真填写。答案无正误之分, 且不影响到任何成绩, 仅为教学研究所用。!

1、请写出下列因果类连接词或词组的意思

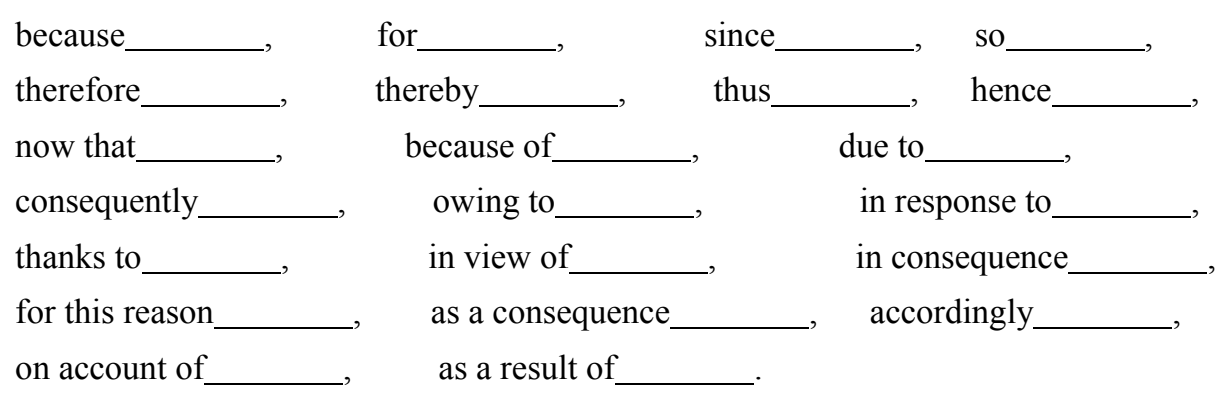

2、请勾出你在写作中常用的因果类连接词

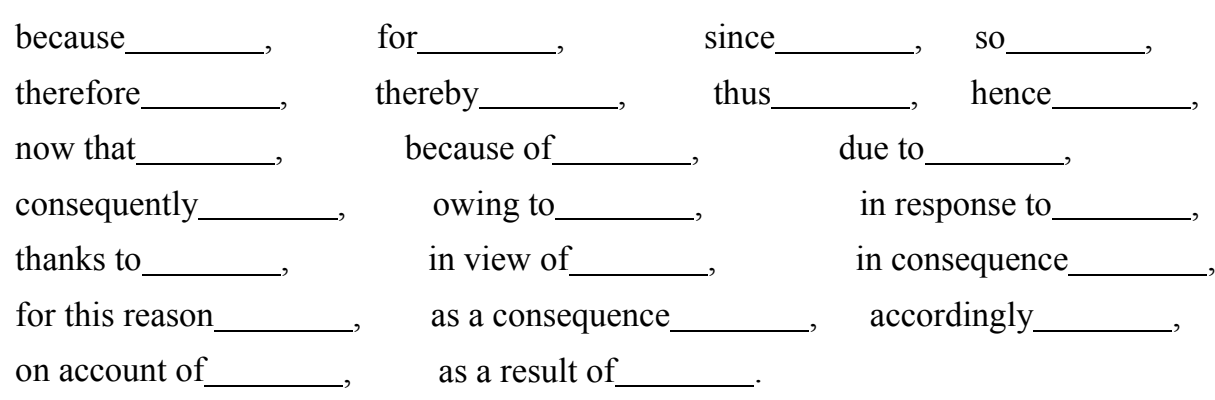

3、请勾出你在口语中常用的因果类连接词

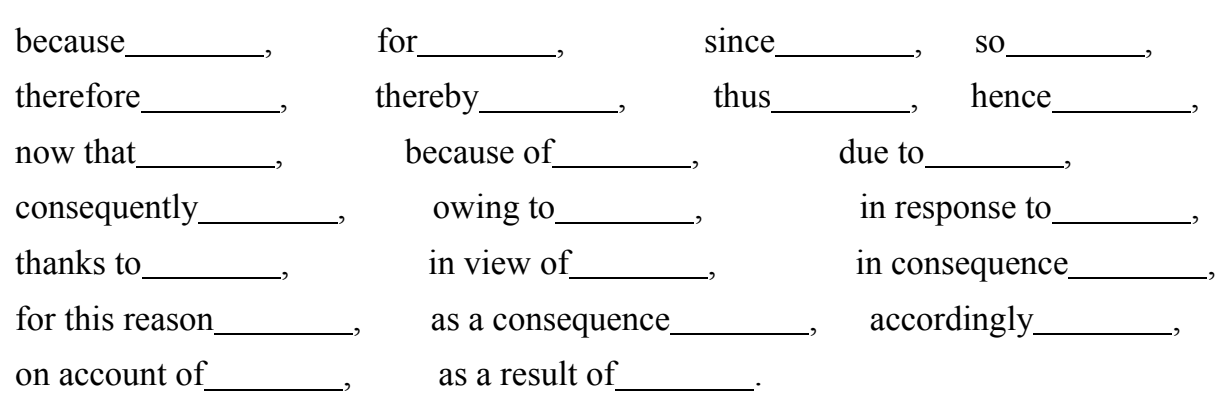

4、为什么经常使用这些因果连接词?
A、不会犯错误
B、与汉语类似
C、无意识地使用
D、其他原因

5、限时考试中, 你符合下列哪种情况？
A、时间有限, 选择简单、熟悉的因果词
B、选择与汉语类似的因果词
C、有意识避开使用最常见、最简单的因果词
D、其他情况 
6、非限制时写作中, 你符合下列哪种情况?
A、选择简单、熟悉的因果词
B、选择与汉语类似的因果词
C、有意识避开使用最常见、最简单的因果词
D、其他情况

7、在英语写作/口语中，你使用因果类连接词的频率如何？
A、总是
B、经常
C、有时
D、从不

8、在英语写作/口语中, 你会联想汉语的因果类连接词吗?
A、总是
B、经常
C、有时
D、从不

9、你怎样看待英语写作和口语中因果类连接词的作用?
A、非常重要
B、重要
C、不是很重要
D、不重要

10、你的英语老师会在教学中教授因果类连接词的知识吗?
A、总是
B、经常
C、有时
D、从不

11、你的英语老师会在写作或口语指导课上强调哪些连接词属于书面语语体、哪些是口语语体吗?
A、总是
B、经常
C、有时
D、从不

12、你怎样看待在课堂上讲解和练习因果类连接词?
A、很有必要
B、有必要
C、有点必要
D、没必要

\section{Copyrights}

Copyright for this article is retained by the author(s), with first publication rights granted to the journal.

This is an open-access article distributed under the terms and conditions of the Creative Commons Attribution license (http://creativecommons.org/licenses/by/3.0/). 